\title{
EAC Competition Law
}

\author{
Joyce Karanja-Ng'ang'a
}

\subsection{Introduction and Background}

Competition law is concerned with the structure and behaviour of enterprises in the market. ${ }^{1}$ It aims to create a market in which producers and traders would compete freely on the quality of products and services they offer and the prices they charge rather than through the improper exercise of market power, whether acquired unilaterally or in concert with others. ${ }^{2}$ Further, competition law is important to provide a framework for competitive activity as it seeks to encourage and improve the competitive environment, create a conducive environment for investment and promote the transfer of the benefits to consumers. More broadly, competition policy is designed to address "industry structures and practices that give excessive market power to sellers to raise prices above, or reduce quantities below the levels that would prevail in competitive markets." 3

The increasing number of regional trade agreements for closer economic integration through removal of barriers against free movement of goods and services and labour, has raised the need for competition law and policy at the regional level. ${ }^{4}$ The Secretary General of the Common Markets for Eastern and Southern Africa ("COMESA") in 2004 stated the issue as follows:

as the regional economy integrates more deeply, the necessity for appropriate policy instruments and tools is becoming increasingly urgent and, in this regard, a competition policy is important to ensure observance

1 Melaku Geboye Desta, 'Exemptions from Competition Law in Regional Trade Agreements: A study based on experiences in agriculture and energy sectors' in Philippe Bruisk, Ana Maria Alvarez, Lucian Cernat (eds), in United Nations Conference on Trade and Development, Competition Provisions in Regional Trade Agreements: How to Assure Development Gains (United Nations 2005).

2 Ibid. 2.

3 Tarullo, D.K. (2000), Norms and Institutions in global competition policy, American Journal of International Law, 94, 478-504.

4 Supra.1. 
of good corporate governance and promoting equitable and harmonious economic development. ${ }^{5}$

This Chapter examines competition law in the East African Community ("EAC") which is the regional intergovernmental organization of the Republics of Burundi, Kenya, Rwanda, Tanzania, Uganda and South Sudan" (the "Partner States"), ${ }^{7}$ headquartered in Arusha, Tanzania. In order to ensure, protect and promote fair trade and consumer welfare in the EAC region, the Council of Ministers of the EAC adopted a competition policy in 2004. ${ }^{8}$ Subsequently the East African Legislative Assembly (the "Assembly") enacted the East African Community Competition Act in $2006^{9}$ (the "EAC Competition Act"). Additionally, the East African Community Regulations (the "EAC Competition Regulations") were adopted in 2010 by the Council of Ministers. The EAC Competition Regulations mainly contain procedural requirements on the various applications of the East African Community Competition Authority (the "EAC Competition Authority") as provided in the EAC Competition Act. The EAC Competition Regulations are to come into force on such date as the EAC Council of Ministers may appoint by notice in the EAC Gazette.

The EAC Competition Act came into effect on 1 December 2014 by an EAC Gazette notice dated 23 January 2015. It has been ratified by all Partner States but the enforcement and operationalization of the EAC Competition Act has not yet commenced. This is primarily linked to the delay in constituting the EAC Competition Authority which is established under the EAC Competition Act ${ }^{10}$ and charged with enforcing the EAC Competition Act. ${ }^{11}$ Notably, the Council of Ministers has now approved commissioners to the EAC Competition Authority and appointed a secretariat which is currently in the process of recruiting technical staff. ${ }^{12}$ The EAC Competition Authority is expected to begin operations in the third or fourth quarter of 2016.

5 Erastus Mwencha, Secretary General, comesa: Ministerial Roundtable, (Cairo 2004).

6 South Sudan was admitted into the EAC by a resolution of the 17th Ordinary session of the EAC Heads of State Summit held in Arusha, Tanzania on 3 February 2016.

7 Somalia has also applied in 2011 for entry into the EAC but they have not yet been admitted.

8 East African Community Competition Policy, 2004.

9 Gazette of the East African Community No. 002 Vol AT 1-003 dated September 2007.

$10 \quad$ EAC Competition Act, s 37.

11 An interim organisational structure and budget for the EAC Competition Authority for the 2016/2017 financial year has also been approved by the Partner States.

12 Adam Ihucha, 'EAC Competition Authority to Start Operations in July' (The East African Standard 18 June 2016) <http://www.theeastafrican.co.ke/business/EAC-competition- 
According to TradeMark East Africa, ${ }^{13}$ there have been other major challenges that have contributed to delays in operationalizing the EAC Competition Act. To begin with, there has been inadequate funding from Partner States to enable the EAC Competition Authority to start its operations and function effectively across the region..$^{14}$ Furthermore, there are jurisdictional conflicts between the EAC competition regime and the national competition regimes leading to disharmony and enforcement hurdles. Similarly, amendments to the EAC competition legislation that would bring regional harmony have been delayed by national governments..$^{15}$ In addition, the economies of the Partner States are at different levels of development, and there is still a quest for protectionism by the governments of some of the Partner States. ${ }^{16}$

More importantly, there has been a lack of political will and vested interests by the governments of some Partner States, who have shown reluctance to be supervised at the regional level on national economic matters such as national procurement law and industrial policy. ${ }^{17}$ Another major challenge is that the interface between sector regulators and national competition authorities has not been properly established in the Partner States.

The EAC Competition Act gives the EAC Competition Authority exclusive original jurisdiction in the determination of violations of the EAC Competition Act. This means that national competition authorities in the Partner States will not have the jurisdiction to make determinations or findings based on the East African Competition Act. Therefore, the jurisdiction of national competition authorities is limited to enforcement of their own national laws. The enforcement authorities of Partner States are also obliged to enforce the decisions made by the EAC Competition Authority. ${ }^{18}$ Consequently, each Partner State

authority-to-start-operations-in-July-///256o/3255818/-/b6nmku/-/index.html> accessed 12 July 2016.

13 Elizabeth Sisenda, 'Why EAC Competition Law is Key in Efforts to Spur Growth' (The Business Daily, 2 November 2015)<h http://www.businessdailyafrica.com/Opinion-andAnalysis/EAC-competition-law-to-spur-growth/-/539548/2939986/-/12kt4ny/-/index .html> accessed 27 January 2016.

14 Ibid. The EAC Legislative Assembly approved a budget of USD 587,565 for the operationalization of the EAC Competition Authority in the 2016/2017 financial year which begins on 1 July 2016 and ends on 30 June 2017. Please also see <http://www.theeastafrican.co.ke/ news/EAC-unveils-austere-budget-for-2016-17-/-/2558/3222616/-/14lj4lgz/-/index.html >.

15 Ibid. 15.

16 Ibid. 15.

17 Ibid. 15 .

18 EAC Competition Act, s 44(6). 
is required to establish its own competition legislation, policy and regulatory authority.

At present, all Partner States have enacted national competition laws except Uganda. However, the Partner States are at different stages of implementing their competition laws. Kenya and Tanzania have functioning competition enforcement organs charged with enforcing their respective national competition laws. These are the Competition Authority of Kenya ${ }^{19}$ (the "CAK") and the Fair Competition Commission ${ }^{20}$ (the "FCC"), respectively.

Rwanda is in the process of setting up an enforcement authority, the Rwanda Competition and Inspectorate Authority, to deal specifically with competition matters. In the meantime, Rwanda's competition law, Law No $36 / 2012$ Relating to Competition and Consumer Protection of 21 September 2012, is being enforced by the Ministry of Trade and Industry. In Burundi, the relevant competition legislation is the Competition Act, Law $\mathrm{N}^{\circ} 1 / 06$ of 25 March 2010, which establishes the Competition Commission. However, to date, the Burundi Act has not yet been implemented nor has the Competition Commission been operationalised.

As for Uganda, no specific competition regime has been put in place to date, even though over the years Bills have been submitted to Uganda's Cabinet and Parliament, in particular a Competition Bill issued by the Uganda Law Reform Commission, so far unsuccessfully. ${ }^{21}$ Uganda, however has in place sector specific laws which address competition regulation in particular industries. These include, the Uganda Communications Act (Cap 106 of the laws of Uganda), the Electricity Act, 1999 (Cap. 145); the Financial Institutions Act (Cap. 54); the Petroleum Supply Act, 2003 and the Insurance Act (Cap. 213) as amended by the Insurance (Amendment) Act, 2011.

In light of the above, any comparative analysis to the practice of a Partner State in this Chapter will focus on the practice in Kenya and Tanzania, which already have competition regulation that is actively being enforced.

Kenya, Rwanda and Uganda are also members of COMESA and are subject to the COMESA competition regime comprised of the COMESA Competition Regulations, 2004 and the COMESA Competition Rules, 2004. ${ }^{22}$ Further,

\footnotetext{
19 Established under section 7 of the Kenyan Competition Act, Act No.12 of 2010.

20 Established by the Fair Competition Act, No.8 of 2003.

21 Anne Brigot-Laperrousaz, 'East-Africa and Antitrust: Enforcement of EAC Competition Act', (African Antitrust \& Competition Law, 14 January 2016), <http://africanantitrust.com/ category/burundi/> accessed 8 January 2016. 
Tanzania is a member of the Southern African Development Community ("SADC"). Although SADC does not have a binding competition law in force, it signed a Declaration on Regional Cooperation in Competition and Consumer Policies in September 2009, which sets out a cooperation framework on competition policy for the SADC Free Trade Area that helps streamline international trade and support economic growth. ${ }^{23}$ Similarly, Tanzania is required to act within the spirit of this Declaration.

Therefore, an additional challenge with implementation of the EAC competition regime, in particular for Kenya and Tanzania is that no mechanism has yet been established to facilitate the interaction between the EAC Competition law, their national competition laws and comesa (in the case of Kenya). As such, a merger transaction in Kenya, for example, may fall within the ambit of three separate regimes, and in theory would need to be notified to the EAC Competition Authority, the Competition Authority of Kenya and ComesA Competition Commission. This multiplicity of notifications would result in increased transaction costs and possible delays in obtaining merger clearances, making these regions potentially less attractive to investments. This is contrary to the objectives of the EAC competition regime which we examine in detail below. Further, there is the risk of contradicting decisions being issued by the different regulators and forum shopping where merger parties choose to notify only to the regulator they think is most likely to approve their transaction.

\subsection{Objectives and Application of the EAC Competition Act}

The EAC Competition Act states that the objectives of the competition policy and practice in the EAC shall be, among other things:

(a) to enhance the welfare of the people in the EAc by protecting all market participants' freedom to compete by prohibiting anti-competitive practices; protecting the opening of Partner States' markets against the creation of barriers to interstate trade and economic transactions by market participants; guaranteeing equal opportunities in the EAC to all market participants in the EAC and especially to small and medium-sized enterprises; guaranteeing a level playing field for all market participants in the EAC by eliminating any discrimination by Partner States on the basis of nationality or residence;

23 Southern African Development Community, 'Competition Policy', <http://www.sadc.int/ themes/economic-development/trade/competition-policy/> accessed 8 January 2016. 
(b) to enhance the competitiveness of EAC enterprises in world markets by exposing them to competition within the EAC;

(c) to create an environment which is conducive to investment in the EAC;

(d) to bring the EAC's competition policy and practice in line with international best practice; and

(e) to strengthen the Partner States' role in relevant international organizations. ${ }^{24}$

The EAC Competition Act applies to all economic activities and sectors having cross-border effect. ${ }^{25}$ The extent of the cross-border effect is not expressly defined but it is implied from the provisions of the EAC Competition Act to be within the East African Community.

The EAC Competition Act does not apply to: any conduct of persons acting in their capacity as consumers; collective industrial bargaining; and sovereign acts of the Partner States. ${ }^{26}$ It also excludes its application to restraints on competition imposed by and resulting from a Partner State's regulation of specific sectors or industries to the extent that the anti-competitive conduct is required by such regulation within that Partner State's own jurisdiction, ${ }^{27}-$ presumably a carve-out for parastatal monopolies or state aided firms.

The EAC Competition Act deals with specific aspects which would affect competition in the EAC including: mergers and acquisitions, prohibited trade practices, abuse of dominance, Partner State subsidies and public procurement. Most of the provisions contained in the EAC Competition Act are broadly drafted and do not provide the means of interpretation or procedures for implementation. Once operationalized, it is expected that the EAC Competition Authority, will publish guidelines, rules or regulations setting out its application of the provisions of the EAC Competition Act and providing more specific details of the way in which the EAC Competition Act is to be applied; this was the approach taken by the com EsA Competition Commission to which Kenya, Rwanda and Uganda are members. It will be critical that any such guidelines, rules and regulations are developed whilst taking into account the competition legislation in Partner States.

We consider the specific provisions of the EAC Competition Act governing cartels, abuse of dominance and concentrations below.

\footnotetext{
24 EAC Competition Act, s 3.

25 EAC Competition Act, s 4(1).

26 EAC Competition Act, s 4(2).

27 EAC Competition Act, s 4(3).
} 
Central to each of these provisions is the definition of the relevant market. The concept of relevant market is defined in Section 5(5) of the EAC Competition Act. For the purposes of the Act, the area of the relevant market is to be determined by "the substitutability of goods or services for consumers in light of their intended use, characteristics and prices as well as by the substitutability of different sources of supply located in different regions." 28

\subsection{Cartels}

Black's Law Dictionary defines a cartel as, 'a combination of producers or sellers that join together to control a product's production or price. ${ }^{29}$ It is also defined as an association of firms with common interest seeking to prevent extreme competition, allocate markets or share knowledge. ${ }^{30}$

OECD explains a cartel as a formal agreement among firms in an oligopolistic industry. ${ }^{31}$ Cartel members may agree on such matters as prices, total industry output, market shares, allocation of customers, allocation of territories, bidrigging, establishment of common sales agencies, and the division of profits or combination of these. ${ }^{32}$ Cartels or cartel behaviour attempts to emulate that of a monopoly by restricting industry output, raising or fixing prices in order to earn higher profits. ${ }^{33}$ This then hinders competition by limiting the supply of specific trade goods or increasing the prices of such goods and services, making them unnecessarily expensive and hence injuring the consumer. ${ }^{34}$

Cartel conduct is prohibited in most competition laws around the world including those in the Partner States that presently have competition legislation; and the EAC Competition Act is no different. The EAC Competition Act provides that a person shall not engage in a concerted practice if that practice has, or is intended to have, an anti-competitive effect in the relevant market, ${ }^{35}$ unless permitted by the EAC Competition Authority. ${ }^{36}$ A "concerted practice"

28 EAC Competition Act, s 5(5).

29 Bryan A. Garner, Black's Law Dictionary, (8th edn, West Publishing Co., 2004).

30 Ibid.

31 R.S. Khemani and D.M. Shapiro, 'Glossary of Industrial Organisation Economics and Competition Law' (Directorate for Financial, Fiscal and Enterprise Affairs, OECD, 1993), $<$ https://stats.oecd.org/glossary/detail.asp?ID=3157> accessed on 8 February 2016.

$32 \quad$ Ibid.

33 Ibid.

34 'Cartels and anti-competitive agreements' www.oecd.org.

35 EAC Competition Act, s 5(1).

$36 \quad$ EAC Competition Act, s 7 . 
is defined to mean, "any agreement, arrangement or understanding, formal or informal, written or oral, open or clandestine, between competitors." ${ }^{37}$ From the definition, the cartel provisions of the EAC Competition Act appear to cover only cooperation among competitors, that is, horizontal agreements. However, this may arguably include vertical arrangements with underlying horizontal purposes. ${ }^{38}$

More specifically, the EAC Competition Act prohibits the following practices: $^{39}$

(a) collusion by competitors to fix prices;

(b) collusive tendering and bid rigging;

(c) collusive market or customer allocation;

(d) quantitative restraints on investment, input, output or sales;

(e) barring competitors from access to the market or from access to an association or arrangement which is essential for competition; and

(f) concerted practice restricting movement of goods within the EAC.

Additionally, any concerted practice by undertakings restricting exports to or imports from foreign countries is prohibited, if it is intended to have anticompetitive effects on the relevant market within the EAC or on access of EAC undertakings to exports or imports.

Any person who contravenes the above provisions is liable to a fine of not more than USD 100,000. In this respect, the EAC Competition Act does not expressly provide an appeal mechanism for a person dissatisfied with the decision of the EAC Competition Authority. However, the EAC Competition Act generally empowers the East African Court of Justice (the "EACJ" $)^{40}$ to determine any question with respect to any action of the EAC Competition

$37 \quad$ EAC Competition Act, s 2.

38 Please note however, the provisions of the EAC Competition Act relating to abuse of dominance also consider the vertical effects of the actions of an undertaking holding a dominant position by prohibiting a dominant firm from engaging in practices whereby: (a) the resale prices or conditions are directly or indirectly fixed; (b) customers or competitors are foreclosed from access to sources of supply or from access to outlets; (c) movement of goods or services between different geographical areas are restricted; and (d) an intellectual property right is used in any way that goes beyond the limits of its legal protection.

39 EAC Competition Act, s 5(2).

40 The East African Court of Justice is one of the organs of the EAC established under Article 9 of the Treaty for the Establishment of the East African Community. EACJ's major responsibility is to ensure the adherence to law in the interpretation and application of and compliance with the EAC Treaty. 
Authority. Consequently, an aggrieved person may appeal a decision of the EAC Competition Authority pursuant to this provision, to the EACJ.

However, the EAC Competition Act exempts certain practices from the application of the provisions stated above. Thus, in situations where the combined market share of the competitors does not exceed $10 \%$ of the relevant market, the undertakings will not be prohibited from engaging in quantitative restraints on investment, input, output or sales or from engaging in concerted practices restricting movement of goods within the EAC. ${ }^{41}$

Additionally, where the combined market share of the parties involved in the concerted practice does not exceed $20 \%$ of the relevant market and the agreement relating to the concerted practice does not contain any of the specifically prohibited practices outlined in (a)-(f) above, the prohibition will not apply to the following practices: joint research and development; specialization or distribution; and standardization of products or services. ${ }^{42}$

The EAC Competition Authority may also exempt any other category of concerted practice, provided it has objectives which lead to the improvement of production or distribution and whose beneficial effects, in the opinion of the EAC Competition Authority, outweighs its negative effects on competition provided that the combined market share of the parties involved in the concerted practice does not exceed $20 \%$ of the relevant market. ${ }^{43}$

Any person ${ }^{44}$ who intends to engage in a concerted practice which does not fall into the exemptions discussed above, must apply to the EAC Competition Authority for permission. The procedure for the exemption application is provided in the EAC Competition Regulations. The application must be made in the prescribed form ${ }^{45}$ provided in the EAC Competition Regulations, filed together with a detailed statement setting out the reasons why the concerted practice should be permitted and accompanied by the prescribed fee ${ }^{46}$ (which has not yet been prescribed).

Under the EAC Competition Act, the EAC Competition Authority is required to determine the exemption application within 45 days from the receipt of

\footnotetext{
41 EAC Competition Act, s 6(1).

42 EAC Competition Act, s 6(2).

43 EAC Competition Act, s 6(4).

44 The Laws of The Community (Interpretation) Act, 2004, section 2, a person is defined to include a company, corporation and association or body of persons, corporate or unincorporated.

45 EAC Competition Regulations, Regulation 16(1).

46 EAC Competition Regulations, Regulation 16(2).
} 
the application and communicate the decision to the applicant. ${ }^{47}$ If the EAC Competition Authority does not communicate a decision on the application within the stipulated time, the exemption application shall be deemed to have been approved. ${ }^{48}$ Notably, unlike most of the Partner States' existing competition laws, for example Kenya, neither the EAC Competition Act nor the EAC Competition Regulations provide for an extension of the prescribed timelines. This means that the EAC Competition Authority would need to make any requests for additional information, raise any queries or hold any conference hearings within the 45 day period in which it is required to make and communicate its decision.

A person who engages in a concerted practice without the permission of the EAC Competition Authority commits an offence and is liable to a fine of not more than USD 10,000. It is not clear from the EAC Competition Act whether this penalty is in addition to, or instead of the USD. 100,000 penalty prescribed for breach of the provisions on concerted practices stated above. This is an issue that will perhaps be clarified by the EAC Competition Authority once it is operationalized.

In addition, any agreement that constitutes a concerted practice is void. ${ }^{49}$

\subsection{Abuse of a Dominant Position}

The EAC Competition Act defines a dominant position as:

a position of economic strength enjoyed by one undertaking individually or by more undertakings collectively which enables them to prevent effective competition being maintained in the relevant market by giving the undertaking the power to behave to a material extent independently of its competitors, customers and consumers and in particular to foreclose other undertakings from competing in the relevant market. ${ }^{50}$

The definition of dominant position above is broad and gives the EAC Competition Authority a lot of discretion in determining whether a firm holds a dominant position. Notably, this can be compared to the EU where the relevant provisions do not provide a definition of "dominant position" and the

\footnotetext{
$47 \quad$ EAC Competition Act, s 7(3); EAC Competition Regulations, Regulations 16(3).

48 EAC Competition Act, s 7(5); EAC Competition Regulations, Regulations 16(4).

49 EAC Competition Act, s 26(1).

50 EAC Competition Act, s 2 .
} 
concept of dominance has been elaborated on in case-law and European Commission Guidance Papers. ${ }^{51}$

The definition provided by the EAC Competition Act is different from that in Kenya and Tanzania where the market share held by the relevant firm is one of the main elements taken into account in determining if an entity is a dominant undertaking.

In Kenya, the Competition Act of Kenya defines a dominant undertaking as an undertaking which: ${ }^{52}$

(a) produces, supplies, distributes or otherwise controls not less than onehalf of the total goods of any description which are produced, supplied or distributed in Kenya or any substantial part thereof; or

(b) provides or otherwise controls not less than one-half of the services which are rendered in Kenya or any substantial part thereof. ${ }^{53}$

Additionally, and notwithstanding the above definition, an undertaking in Kenya will be deemed to be dominant if: 54

(i) though not dominant it controls at least $40 \%$ but not more than $50 \%$ of the market share (unless it can show that it does not have market power); or

(ii) it controls less than $40 \%$ of the market share but has market power.

Similarly, in Tanzania an undertaking is deemed to have a dominant position if: acting alone, it can profitably and materially restrain or reduce competition in that market for a significant period of time; and the person's share of the relevant market exceeds $35 \%$. It remains to be seen whether the EAC Competition Authority will apply a market share test when interpreting the dominance of an undertaking.

From the definition of dominant position above, it is clear that the EAC Competition Act covers both the conduct of a single dominant firm as well as collective dominance. This is distinct from Tanzania's Fair Competition Act

51 Case 102/77, Hoffmann-La Roche \& Co AG v Commission [1979] ECR 461; Guidance on the Commission's Enforcement Priorities in Applying Article 82 of the EC Treaty to Abusive Exclusionary Conduct by Dominant Undertakings [2009] OJ C 45/2. See also EU Chapter 14.

$5^{2}$ Competition Act of Kenya, s 4(3).

53 Pursuant to sec.4 of the Competition Act of Kenya, No. 12 of 2010.

54 Competition Act of Kenya, s 34(2). 
whose provisions on dominance are restricted to the conduct of a single firm. ${ }^{55}$ Due to the delicacy of making a finding of collective dominance, which would place a considerable burden of proof on the EAC Competition Authority, especially in establishing a concerted practice affording the parties the power to behave to an appreciable extent independently of their competitors and the consumers, the EAC Competition Authority will need to adopt rules or guidelines setting out the criteria for economic assessment particularly an assessment of the structure of the market. ${ }^{56}$

In addition, an undertaking on which small or medium sized undertakings (SMEs) are dependent on is deemed to be a dominant undertaking and is also bound by the prohibitions set out in (a) and (b) below..$^{57}$

The provisions of the EAC Competition Act on abuse of dominance can be classified into three categories:

(a) prohibitions against exploitation of consumers-under the EAC Competition Act, a dominant undertaking should not: directly or indirectly impose unfairly high selling or unfairly low purchasing prices or other unfair trading conditions; limit production or technical development and innovation to the prejudice of consumers; and discriminate between consumers or suppliers according to non-commercial criteria such as nationality or residence. 58

(b) prohibition against exclusion of competitors-a dominant undertaking should not engage in any practice that excludes, or is intended to exclude, its competitors from the market by means of: predatory pricing; price squeezing or cross subsidization. ${ }^{59}$ Further, a dominant undertaking in the relevant market should not engage in a practice that harms the competitive position of competitors on downstream or upstream markets by: a refusal to deal; a refusal of access to an essential facility; tying arrangements; or unjustifiably discriminating among customers or suppliers.

(c) prohibitions relating to vertical agreements that is, agreements within the supply chain - a dominant undertaking in the relevant market should not engage in a practice whereby: the resale prices or conditions

\footnotetext{
55 United Nations Conference for Trade and Development, (2012) Voluntary Peer Review Of Competition Law And Policy: United Republic Of Tanzania, UnCTAD/DITC/CLP/2012/1.

$5^{6}$ Carina Olsson, 'Collective Dominance-Merger Control on Oligopolistic Markets' (2000) Göteborgs Universitet.

57 EAC Competition Act, s 8(2), 9(3).

58 EAC Competition Act, s 8(1).

59 EAC Competition Act, 9(1).
} 
are directly or indirectly fixed; customers or competitors are foreclosed from access to sources of supply or from access to outlets; movement of goods or services between different geographical areas are restricted; or an intellectual property right is used in any way that goes beyond the limits of its legal protection.

Any contravention of the above provisions on abuse of dominance is an offence punishable by either a fine of not more than USD 10,000 or imprisonment for a term of not more than 2 years or both. It is noteworthy that, as in mergers, the national courts in Partner States have jurisdiction in relation to criminal offences under the EAC Competition Act. ${ }^{60}$

\subsection{Concentrations}

Concentrations in the EAC are subject to merger control and the EAC Competition Authority must be notified of them promptly upon the conclusion of the agreement in respect of a merger or an acquisition. ${ }^{61}$ It is notable that an agreement will be considered to be as such, irrespective of whether it is in writing or not. This notification is required to be made by the undertaking acquiring control through the merger or acquisition. ${ }^{62}$

The EAC competition regime is suspensory and therefore parties cannot implement a proposed merger or acquisition before obtaining the approval of the EAC Competition Authority. However, the EAC Competition Act contains deemed approval provisions discussed under this heading below.

The EAC Competition Act defines a merger as "... an amalgamation orjoining of two or more firms into an existing firm or to form a new firm." ${ }^{63}$ Furthermore, it defines an acquisition as "any acquisition by an undertaking of direct or indirect control of the whole or part of one or more other undertakings, irrespective of whether the acquisition is effected by merger, consolidation, take-over, purchase of securities or assets, contract or by any other means." ${ }^{4}$

The EAC Competition Act does not contain a definition of "control". However, it grants the Council of Ministers the power to make regulations generally for

\footnotetext{
6o EAC Competition Act, s 48(2).

61 EAC Competition Act, s 11(1) (2).

62 EAC Competition Act, s 11(3).

63 EAC Competition Act, s 2.

64 EAC Competition Act, s 2.
} 
the carrying into effect of the provisions of the EAC Competition Act. ${ }^{65}$ The Council of Ministers, exercising this power, may also pass regulations providing a definition of control for purposes of the EAC Competition Act.

Hopefully, such rules or regulations will be developed through a process of consultation with stakeholders in Partner States. As stated above, it is likely that the EAC Competition Authority will be influenced by the interpretation of control in the competition laws and decisions of the competition authorities of the EAC Partner States, ${ }^{66}$ as well as the general practices of other regional regulators such as the COMESA Competition Commission. ${ }^{67}$

The other likelihood is that rules or guidelines will be issued by the EAC Competition Authority to provide further guidance in this respect. It is useful to note that this is the approach that was taken by the COMESA Competition

$65 \quad$ EAC Competition Act, s 49.

66 Section 41(3) of the Kenyan Competition Act defines control in terms of the specific circumstances in which a person would be deemed to have control of an undertaking. Thus, a person 'controls' an undertaking if that person: (i) beneficially owns more than one half of the issued share capital of the undertaking; (ii) is entitled to vote a majority of the votes that may be cast at a general meeting of the undertaking, or has the ability to control the voting of a majority of those votes, either directly or through a controlled entity of that undertaking; (iii) is able to appoint, or to veto the appointment of, a majority of the directors of the undertaking; (iii) is a holding company, and the undertaking is a subsidiary of that company as contemplated in the Companies Act; or (iv) in the case of the undertaking being a trust, has the ability to control the majority of the votes of the trustees or to appoint the majority of the trustees or to appoint or change the majority of the beneficiaries of the trust; (v) in the case of the undertaking being a nominee undertaking, owns the majority of the members' interest or controls directly or has the right to control the majority of members' votes in the nominee undertaking; or (vi) has the ability to materially influence the policy of the undertaking in a manner comparable to a person who, in ordinary commercial practice, can exercise an element of control referred to above.

Section 4(2) of Tanzania's Fair Competition Act provides that, 'a body corporate shall control another body corporate within the meaning of sub-section (1) if the first-mentioned body corporate: (i) owns or controls a majority of the shares carrying the right to vote at a general meeting of the other body corporate; or (ii) has the power to control the composition of a majority of the board of directors or other governing organ of the other of body corporate; or (iii) has the power to make decisions in respect of the conduct of the affairs of the other body corporate.'

67 In comesa (which affects Kenya, Rwanda and Uganda), the comesa Competition Commission published guidelines, the comesa Merger Assessment Guidelines, 2014 which confirmed the COMESA Competition Commission's previous practice as at the time of their adoption that, whether a transaction is a 'merger' depends on whether control is acquired-and 'control' is based on whether a party has the possibility of exercising decisive influence over an undertaking or asset. 
Commission. At the moment, there are no merger thresholds specified by either the EAC Competition Act or the EAC Competition Regulations and consequently, all mergers having a cross-border effect within the EAC are notifiable to the EAC Competition Authority. The EAC Competition Act also does not provide the meaning of "cross-border effect". It is not clear whether crossborder effect means that the proposed merger or acquisition affects at least two Partner States or whether it must affect more than two Partner States. Again, this will hopefully be clarified by the EAC Competition Authority once it is operationalized. However, this means that mergers and acquisitions that are confined within the national boundaries of a Partner State would not be subject to the application of the EAC Competition Act; instead, national competition laws (if any) would apply. However, the lack of merger thresholds means that every transaction that qualifies as a merger or an acquisition with cross-border effect under the EAC Competition Act would be notifiable and would result in the EAC Competition Authority utilizing its limited resources on transactions that are too small to affect trade between the Partner States. By way of observation, this is how the COMESA Competition Regulations were initially operationalized and the period following their commencement caused chaos and uncertainty for transactions affecting businesses in the Common Market. It is hoped that the EAC Competition Authority would learn from the shortcomings of the COMESA Competition Commission. Furthermore, this can be contrasted to the EU system in which the EU Merger Regulation establishes certain turnover thresholds which need to be satisfied in order to trigger notification to the EU Competition Authority. 68

A merger or acquisition carried out in the absence of an authorizing order by the EAC Competition Authority is of no legal effect. ${ }^{69}$ The EAC Competition Authority is mandated to order the divestiture of any merger or acquisition undertaken in contravention of the EAC Competition Act. ${ }^{70}$

Any person found guilty of failing to obtain an authorising order from the EAC Competition Authority prior to a merger will be liable upon conviction to imprisonment for a term not exceeding 2 years or to a fine not exceeding USD 10,000 , or both. ${ }^{71}$ The national courts in Partner States have jurisdiction in relation to criminal offences under the EAC Competition Act. ${ }^{72}$

68 Articles 1(2) and (3) of Council Regulation (EC) No. 139/2004.See also EU Chapter 14.

69 EAC Competition Act, s 12(1)(4).

70 EAC Competition Act, s 26(2).

71 EAC Competition Act, $\mathrm{s} 48$.

$72 \quad$ EAC Competition Act, s 48(2). 
The test that the EAC Competition Authority will use when assessing a merger is whether it will lead to the creation, or strengthening of an already dominant position, thereby lessening competition in the relevant market. More particularly, Section 13(2) of the EAC Competition Act provides that the EAC Competition Authority will consider the following factors:

(a) the competitive structure of all markets affected by the merger or acquisition, including the potential competition from both inside and outside the EAC in light of legal or other barriers to entry;

(b) the undertakings in the markets affected, their control of essential facilities, their integration in upstream and downstream markets, and their financial resources;

(c) the competitors and the alternatives available to suppliers and consumers; and

(d) any pro-competitive effects of the merger or acquisition which may outweigh the harmful effects on competition.

The merger notification must be made in the form prescribed in the EAC Competition Regulations, ${ }^{73}$ and submitted to the EAC Competition Authority together with any relevant documents supporting the intended merger or acquisition. ${ }^{74}$ Upon the issuance of an acknowledgment of receipt of notification of an intended merger or acquisition, the EAC Competition Authority is mandated to publish a notice of the intended merger in at least two newspapers of national circulation in each Partner State and on the EAC website. ${ }^{75}$ The purpose of this notice is to invite interested persons to express their views on the proposed merger or acquisition within 14 days of publication of the notice.

The EAC Competition Regulations also allow any interested person to submit any relevant document to the EAC Competition Authority expressing their views on the merger or acquisition at hand. ${ }^{76}$ The EAC Competition Authority may then utilize this information in considering the merger or acquisition as it deems fit.

73 Form EACCA 1 provided in the Schedule to the EAC Competition Regulations.

74 The prescribed form (Form EACCA 1) prescribes the following supporting documents: memorandum and articles of association, copies of audited annual financial statements for the last three years, strategic business plans, certificates of incorporation/registration, merger agreement, and other relevant documents.

$76 \quad$ EAC Competition Regulations, Regulation 8(1). 
Upon assessing the intended merger or acquisition, the Authority may either: approve the merger or acquisition with or without conditions; decide that the intended merger or acquisition falls outside the jurisdiction of the EAC Competition Act; or reject the intended merger or acquisition. ${ }^{77}$ In the event that the EAC Competition Authority decides that the merger is outside the jurisdiction of the EAC Competition Act, then it is required to refund $75 \%$ of the filing fee paid in respect of the merger notification. No fees have yet been prescribed for filing a merger notification to the EAC Competition Authority.

The EAC Competition Authority is required to make a decision within 45 calendar days of the notification requirements being satisfied. ${ }^{78}$ If the EAC Competition Authority has not communicated its decision within the stipulated time period, ${ }^{79}$ the merger or acquisition may be implemented. This provision will help to deal with any potential delays in determining applications. Due to the lack of merger thresholds it is expected that the EAC Competition Authority may initially be inundated with applications since, in the absence of any thresholds or contrary legislative instruments, all mergers and acquisitions having cross-border effects would be notifiable to it.

Where the EAC Competition Authority rejects a merger or acquisition application, the merging parties may appeal the decision of the EAC Competition Authority to the Council of Ministers. ${ }^{80}$ The Council of Ministers may only approve a merger or acquisition if it is satisfied that the merger or acquisition is to fulfil an overriding public interest. ${ }^{81}$

The EAC Competition Act does not expressly stipulate the factors to be considered by the Council of Ministers in determining whether a merger or acquisition fulfils an overriding public interest. However, it is expected that the Council of Ministers will be guided by the objectives of the EAC as set out in the Treaty for the Establishment of the East African Community. These objectives are to develop policies and programmes aimed at widening and deepening co-operation among the Partner States in political, economic, social and cultural fields, research and technology, defence, security and legal and judicial affairs, for their mutual benefit. ${ }^{82}$ In this respect, the EAC seeks to, among

77 EAC Competition Regulations, Regulation 8(2).

78 Articles 1(2) and (3) of Council Regulation (EC) No. 139/2004. See also EU Chapter 14.

79 EAC Competition Act, s 12(1)(4).

8o EAC Competition Act, s 26(2).

81 EAC Competition Act, $\mathrm{s} 48$.

82 EAC Competition Act, s 48(2). 
other things, ensure: the attainment of sustainable growth and development of the Partner States by the promotion of a more balanced and harmonious development of the Partner States; and the strengthening and consolidation of co-operation in agreed fields that would lead to equitable economic development within the Partner States and which would in turn, raise the standard of living and improve the quality of life of their populations. ${ }^{83}$

\subsection{State Aids as a Prohibited Business Practice}

The EAC Competition Act does not define "state aid". State aid is also not provided in the national competition laws of the Partner States. The EAC Competition Authority would perhaps need to look to other jurisdictions with more developed competition law in implementing the State aid provisions of the EAC Competition Act, including the European Union. The European Commission defines state aid as an advantage in any form whatsoever conferred on a selective basis to undertakings by national public authorities. ${ }^{84}$ According to the European Commission, to constitute State aid, a measure needs satisfy the following:

there has been an intervention by the State or through State resources which take the forms of either a tax relief, grant, government holding of all or part of a company, or providing goods and services on preferential terms; the intervention gives the recipient an advantage on a selective basis, for example to specific companies or industry sectors, or to companies located in specific regions; competition has been or may be distorted; and the intervention is likely to affect trade between Member States. ${ }^{85}$

83 Form EACCA 1 provided in the Schedule to the EAC Competition Regulations.

84 The prescribed form (Form EACCA 1) prescribes the following supporting documents: memorandum and articles of association, copies of audited annual financial statements for the last three years, strategic business plans, certificates of incorporation/registration, merger agreement, and other relevant documents.

85 EAC Competition Regulations, Regulation 7. 
However, in some circumstances, state aid can promote a well-functioning and equitable economy. ${ }^{86}$

Articles 107 to 109 of the Treaty on the Functioning of the European Union (the "TFEU") contain the substantive and procedural rules on distortions of competition as a result of State measures involving any form of aid to undertakings.

Article $107(1)$ of the TFEU provides that aid granted by a member state or through State resources, in any form whatsoever, which distorts, or threatens to distort, competition by favouring certain undertakings or the production of certain goods, is incompatible with the internal market insofar as such aid affects trade between member states. There are several types of aid which are dejure exempt from the prohibition and which are enumerated in Article 107(2) of the TFEU. ${ }^{87}$ In addition, Article 107(3) of the TFEU provides for the possibility of exemption from the prohibition with the approval of the European Commission. It sets out a number of policy objectives for which state aid may be considered compatible with the internal market, including state aid aimed at: (a) promoting the economic development of areas where the standard of living is abnormally low or where there is serious underemployment; (b) remedying a serious disturbance in the economy of a member state; or (c) promoting the execution of an important project of common European interest.

The European Commission enjoys a wide discretion in assessing the compatibility of aid under Article 107(3) of the TFEU. To this end, the European Commission must conduct a balancing test between economic and social interests on the one hand, against the effects on competition and trade between member states on the other hand. The European Commission also ensures that there is frequent review of the law in ensuring that state aid is boosting the European economy. In this respect, it has adopted policies for assessing specific types of aids such as rescue and restructuring aid, government guarantees, and aid for the sale of land by public bodies.

Similarly, the EAC Competition Act allows each Partner State to grant subsidies to any undertaking if it is of the opinion that it is in the public interest to do so. 88

$86 \quad$ EAC Competition Regulations, Regulation 8(1).

87 EAC Competition Regulations, Regulation 8(2).

88 EAC Competition Act, s 14. 
A Partner State may grant subsidies to $/$ for: $^{89}$

(a) consumers of certain categories of products or services in order to promote social services;

(b) the development of small and medium-sized enterprises;

(c) the restructuring, rationalizing and modernizing of specific sectors of the Partner State's economy;

(d) less developed regions;

(e) research and development;

(f) the financing of a public sector;

(g) the promotion and protection of food security;

(h) the protection of the environment;

(i) the education and training of personnel;

(j) the conservation of the cultural heritage; and

$(k)$ the compensation of damages caused by natural disasters or by macroeconomic disturbances.

The instances listed above essentially comprise the public interest concerns that a Partner State would consider in determining whether to grant a subsidy or not. This list is not exhaustive. Under Section 17(2) of the EAC Competition Act, the Council of Ministers may exempt other categories of subsidies on the recommendation of the EAC Competition Authority. In granting the exemption, the Council of Ministers shall take into account: the materiality of the subsidy for the achievement of its objective; the compatibility of the subsidy with the objectives of the EAC, including the opening of Partner States' markets; and the establishment of a competitive environment in the EAc. For these cases, the Council of Ministers shall determine the duration of every exemption of subsidy so granted. ${ }^{90}$

However, Partner States are prohibited from applying any subsidies which distort or threaten to distort competition within the EAC. ${ }^{91}$ More specifically, the following subsidies are expressly not allowed: ${ }^{92}$

\footnotetext{
$89 \quad$ EAC Competition Act, s 17.

$90 \quad$ EAC Competition Act, $\operatorname{si7}(4)$.

91 EAC Competition Act, s 16(1).

92 EAC Competition Act, s 16(2).
} 
(a) any subsidy for the promotion of exports or imports between the EAC Partner States; and

(b) any subsidy which is granted on the basis of the nationality or residence of persons or country of origin of goods or service.

Before granting any subsidy, a Partner State must notify the EAC Competition Authority. ${ }^{93}$ Where the EAC Competition Authority considers that the subsidy falls under the exemption stated above, it will communicate its decision to the Partner State. If the Partner State is dissatisfied with the EAC Competition Authority's decision, it may refer the matter to the EACJ. ${ }^{94}$ In the case that the EACJ determines that the subsidy is illegal, a Partner State will be required to recover the subsidy from its recipient. ${ }^{95}$

\footnotetext{
93 EAC Competition Act, s 15(1).

94 EAC Competition Act, s 15(3).

95 EAC Competition Act, s 15(4).
} 